\title{
KONCENTRINIŲ PRATIMŲ POVEIKIS RAUMENŲ NUOVARGIUI IR PAŽEIDAI PRIKLAUSOMAI NUO RAUMENŲ TEMPERATŪROS IR TIRIAMOJO LYTIES
}

\author{
Irina Ramanauskiene் $\dot{e}^{1,2}$, Albertas Skurvydas ${ }^{1}$, Saulė Sipavičiené $\dot{1}^{1}$ Dalia Mickevičiené $\dot{1}^{1}$ \\ Laura Daniusevičiūtè $\dot{1}^{1,2}$, Vitas Linonis ${ }^{2}$ \\ Lietuvos kūno kultüros akademija ${ }^{1}$, Kauno technologijos universitetas ${ }^{2}$, Kaunas, Lietuva
}

\begin{abstract}
Irina Ramanauskienė. Biomedicinos mokslų daktarè. Kauno technologijos universiteto Kūno kultūros ir sporto centro, Kūno kultūros katedros lektorè. Mokslinių tyrimų kryptis — raumenų fiziologija: šildymo ir šaldymo poveikis raumenų nuovargiui bei atsigavimui priklausomai nuo lyties ir raumens susitraukimo greičio.
\end{abstract}

\section{SANTRAUKA}

Tyrimo tikslas - nustatyti koncentriniu pratimu poveiki raumenu nuovargiui ir pažeidai priklausomai nuo raumenu temperatūros ir tiriamojo lyties. Tiriamuju kontingenta sudare 19-23 metu moterys $(n=10)(\overline{u g i s}-166,4 \pm 5,6 \mathrm{~cm}$; küno svoris - 56,2 \pm 6,1 kg; riebalu mase - 17\% (10,7 rieb. mase $/ \mathrm{kg})$ ir vyrai $(\mathrm{n}=10)$ (ügis $-177,8 \pm 5,8 \mathrm{~cm}$; kūno svoris - 78,2 $\pm 6,1 \mathrm{~kg}$; riebalu masé - 7,5\% (5,6 rieb. mase / kg), atrinkti atsitiktinés atrankos metodu. Tiriamieji testuoti izokinetiniu dinamometru „Biodex Medical System PRO 3“. Registruotas maksimaliosios jegos momentas (MJM). Buvo atliekami kontroliniai matavimai (3 kartus tiesiant ir lenkiant koja per kelio sqnarifiksuotu $180^{\circ}$ / s greičiu) prieš krūvi, praejjus 10, 30, 60 min ir 24 h po jo. Koncentrinis krūvis - 50 blauzdos tiesimu ir lenkimu $180^{\circ}$ / s greičiu, kai raumenys iprastinès temperatūros (ITR), pašildyti (tiriamieji 45 min kojas laikè šiltoje vonioje, kurios vandens temperatūra - 44 $\pm 1{ }^{\circ} \mathrm{C}$ (Sargeant, 1987) ir pašaldyti (tiriamieji du kartus po 15 min (darydami 10 min pertrauka) panardindavo kojas $\dot{\imath}$ šalta vonia, kurios vandens temperatūra $-15 \pm 1{ }^{\circ} \mathrm{C}$ (Eston, Peters, 1999). Tarp tyrimu buvo daroma ne mažesnè kaip ménesio pertrauka. Vidiné raumenu temperatūra (pradine ir iš karto po raumenu pašildymo bei pašaldymo, po koncentrinio krūvio) buvo matuojama adatiniu termometru. Kreatinkinazès (CK) aktyvumas kraujo serume nustatytas prieš krūvi ir praejus 24 h po jo. Raumenu skausmas subjektyviai vertinamas balais po krūvio praejus $24 \mathrm{~h}$.

Kreatinkinazès (CK) aktyvumas kraujo serume, praejus 24 h po koncentrinio krūvio, reikšmingai padidejjo ir vyru, ir moteru, palyginti su kontroline reikšme ( $<<0,05)$, kai raumuo buvo ìprastinès temperatūros, pašildytas ir pašaldytas. Nustatyta, kad moteru CK aktyvumas kraujo serume reikšmingai skiriasi, kai raumuo ITR ir pašaldytas, vyru - ITR ir pašildytas $(p<0,05)$. Lyginant vyru ir moteru $C K$ aktyvumo kraujo serume iprastinès temperatūros raumenu reikšmes, praejjus 24 h po krūvio, nustatytas statistiškai reikšmingas skirtumas $(p<0,05)$.

Tiek šildymas, tiek šaldymas prieš koncentrini krūvį sumažino netiesiogini raumenu pažeidos simptoma - kreatinkinazès kieki kraujyje praejus 24 h po krūvio, tačiau raumenu skausmo temperatūra nepakeitè. Pasyvus šildymas ir šaldymas nepakeitè nei vyru, nei moteru raumenu nuovargio, atliekant koncentrinius pratimus vidutiniu greičiu.

Raktažodžiai: blauzdos tiesiamieji ir lenkiamieji raumenys, raumenu pasyvus šildymas ir šaldymas, lytis.

\begin{abstract}
IVADAS
$\mathrm{N}$ eiprasti pratimai, labai intensyvios sporto pratybos arba padideję̨s treniruotès krūvis dažnai skatina uždelstą raumenų skausmo atsiradimą ir sukelia raumenų pažeidą (Nosaka et al., 2002; Byrne et al., 2004). Ypač dažnai tai nutinka atliekant ekscentrinius pratimus, kurių metu raumenys po issitempimo pailgejja (Ratkevicius et al., 1998; Skurvydas et al., 2000; Sayers, Clarkson, 2003). Manoma, kad ekscentrinių susitraukimu metu aktyvinamas mažesnis motoneuronų kiekis,
\end{abstract}

negu atliekant to paties galingumo koncentrinius susitraukimus, todèl pažeida yra didesnè (Enoka, 1996). Koncentrinis krūvis mažina raumenų atsparumą ekscentrinių krūvių sukeliamai pažeidai (Gleeson et al., 2003). Z. Zainuddin ir kt. (2006) atliko du ekperimentus, stebėdami kreatinkinazès kieki kraujyje septynias dienas po ekscentrinio (60 alkūnès lenkiamuju judesiu) (pirmas eksperimentas) ir po koncentrinio (600 alkūnès lenkiamujų ir tiesiamuju judesių) krūvio (antras ekperimentas). 
Mokslininkai norèjo patvirtinti hipotezę, kad atlikus koncentrinị krūvị, palyginti su ekscentriniu, sumažès raumenu skausmas ir raumuo greičiau atsigaus po pažeidos, tačiau padarè išvadą, kad po koncentrinio krūvio raumenu skausmas buvo mažesnis, palyginti su ekscentriniu, o raumuo greičiau neatsigavo (Zainuddin et al., 2006).

Ištvermè gali pablogèti dẻl aukštos aplinkos temperatūros (Galloway and Moughan, 1997), taip pat ji priklauso nuo kūno temperatūros krūvio pradžioje (Booth et al., 1997). Pasak M. A. Febbraio (2000), padidejjusi raumenų temperatūra susilpnina griaučių raumenų veiklą, medžiagų apykaitą, ir tai sukelia nuovargi. Po ekscentrinių pratimų raumenų skausmą lydi ne tik raumenu sustingimas, skausmas judesio metu, jautrumas bei patinimas, bet ir jègos mažèjimas (Sayers et al., 2000; Clarkson, Hubal, 2002). Jègos sumažejimas yra vienas informatyviausių raumenų pažeidos kriterijų (Warren et al., 1999).

Mažèjant audinių temperatūrai, mažèja nervų laidumo greitis ir raumeninių verpsčiu aktyvumas. Tai susiję su tempimo reflekso reakcija ir raumenu spazmais, kurie sumažina skausmo, spazmu ciklą ir pati skausmą (Meeusen and Lievens, 1986). W. E. Prentice (1982) tyrè, kaip šildymas, šaldymas ir tempimo pratimai mažina raumenu pažeidos rodiklius. Mokslininkai tvirtina, kad šaldymo ir tempimo derinys buvo daug veiksmingesnis negu raumenų šildymas. Tiriant gyvūnèlius nustatyta, kad patelès yra atsparesnès pažeidai nei patinai. Žmogaus raumenų atsparumas pažeidai nepriklauso nuo lyties (Clarkson, Hubal, 2002). Todèl šio tyrimo tikslas - nustatyti koncentrinių pratimų poveiki raumenų nuovargiui ir pažeidai priklausomai nuo raumenų temperatūros ir tiriamojo lyties.

\section{TYRIMO METODAI}

Tiriamuju kontingentą sudare 19-23 metu moterys $(\mathrm{n}=10)$ (ūgis $-166,4 \pm 5,6 \mathrm{~cm}$; kūno svoris - 56,2 $\pm 6,1 \mathrm{~kg}$; riebalų mase $-17 \%$ $(10,7$ rieb. mase $/ \mathrm{kg})$ ir vyrai $(\mathrm{n}=10)$ (ūgis $177,8 \pm 5,8 \mathrm{~cm}$; kūno svoris $-78,2 \pm 6,1 \mathrm{~kg}$; riebalų masè $-7,5 \%$ (5,6 rieb. masé $/ \mathrm{kg})$. Tyrimas atliktas laikantis $1975 \mathrm{~m}$. Helsinkio deklaracijoje priimtų principų dėl žmonių eksperimentų etikos. Tyrimo protokolas aprobuotas KMU bioetikos komisijoje (Protokolo Nr. P1-80 / 2004).

Prieš kiekvieną eksperimentą moterys buvo klausiamos, kokia tuo metu jų menstruacinio ciklo fazè. Tyrimai atliekami prieš savaitę iki menstruacinio ciklo pradžios arba praejus savaitei nuo jo pradžios. Anot X. A. K. Janse de Jonge (2003), atliekant fizinį krūvî, raumenu jègos kaita priklauso nuo menstruacinio ciklo fazių. Folikulinè (proliferacijos) ir liuteininè (sekreciné) fazè raumenu jègos neveikia, jègos kaita pasireiškia menstruacinès fazès metu. Tyrimai atlikti esant folikulinei (proliferacijos) arba liuteininei (sekrecinei) fazei.

Blauzdos tiesiamųjų ir lenkiamųjų raumenų savybių testavimas. Tiriamieji buvo testuojami „Biodex Medical System PRO 3“ (sertifikuota ISO 9001 EN 46001) - žmogaus raumenu testavimo ir reabilitacijos aparatūra. Prie dinamometro pritvirtinamas papildomas blauzdos itaisas. Nustatyta kelio anatominè sąnario ašis. Tiriamasis apjuostas pečių, liemens, šlaunies diržais. Blauzda sutvirtinama diržu ir susegama sagtimi apatiniame trečdalyje virš kulnakaulio gumburo, koja fiksuojama per kelio sąnari $90^{\circ} \mathrm{kampu}$, pasveriama tada, kai ji fiksuota $72 \pm 5^{\circ} \mathrm{kampu}$ (gravitacinès sunkio jègos momentu). Valdymo skyde pasirenkamas izokinetinis režimas ir koncentrinis susitraukimo tipas. Registruotas maksimaliosios jejgos momentas.

Raumenų pasyvaus šildymo metodika. Tiriamieji sèdèdami ištiestas kojas 45 min laikè šiltoje vonioje, kurios vandens temperatūra $-44 \pm 1^{\circ} \mathrm{C}$, kambario temperatūra $20-22^{\circ} \mathrm{C}$. Vandens i vonia buvo pripilama tiek, kad šlaunys būtų visiškai panardintos vandenyje. Šildymo pabaigoje raumenu temperatūra $3 \mathrm{~cm}$ gylyje padidèjo $\sim 2,7^{\circ} \mathrm{C}$ (Sargeant, 1987; Ramanauskienè ir kt., 2006 b). Vandens temperatūra buvo matuojama vandens termometru, o patalpos - oro termometru.

Raumenų šaldymo metodika. Tiriamieji kojas du kartus po 15 min (darydami 10 min pertrauką) panardindavo i šaltą vonią, kurios vandens temperatūra $-15 \pm 1{ }^{\circ} \mathrm{C}$ (Eston, Peters, 1999). Keturgalvio šlaunies raumens temperatūra $3 \mathrm{~cm}$ gylyje sumažèjo iki $32,5 \pm 0,3^{\circ} \mathrm{C}$ (prieš šaldymą buvo $36,8 \pm 0,2^{\circ} \mathrm{C}$ ) (Ramanauskienè ir kt., 2006 b).

Vidinès raumenų temperatūros matavimo metodika. Vidinè raumenų temperatūra (pradinè ir iš karto po raumens pašildymo, pašaldymo) buvo matuojama adatiniu termometru (Ellab A / S, tipas DM 852, Danija). Dūrio vieta dezinfekuojama 5\% spiritiniu jodo tirpalu. Iduriama i šoninio plačiojo šlaunies raumens (vastus lateralis) vidurini trečdali ( $3 \mathrm{~cm}$ gilumu), šone nuo šlaunikaulio. Adatinis termometras po kiekvieno panaudojimo sterilizuojamas autoklave (gamintojas: M.O.COM Via delle Azlee 1, 20090 Buccinaso, Italija). Sterilizacijos proceso laikas $-30 \mathrm{~min}$, temperatūra $-121^{\circ} \mathrm{C}$.

Kreatinkinazès aktyvumo kraujo serume nustatymas. CK aktyvumas kraujo serume buvo 
vertinamas $1 \mathrm{~h}$ prieš koncentrinị krūvị ir praèjus 24 h po jo (Clarkson, Sayers, 1998). Norint ivvertinti CK aktyvumą kraujo serume, iš tiriamuju rankos venos buvo imamas kraujas (apie $5 \mathrm{ml}$ ). Méginio analizavimo procedūra atlikta Kauno medicinos universiteto kliniku Biochemijos laboratorijoje. Analizė atlikta automatiniu biocheminiu analizatoriumi „Monarch“ (gamintojas - Instrumentation Laboratory SpA, JAV ir Italija).

Raumenų skausmo vertinimo metodika. $\mathrm{Pa}$ gal raumenų skausmą buvo nustatomas raumenų pažeidos dydis (Clarkson, Newham, 1995). Raumenų skausmas subjektyviai vertinamas balais (nuo 0 iki 10: visai nejautè skausmo - 0; jaute nemalonų pojūti -3 ; jaute skausmą -5 ; jautè dideli skausmą - 8; jautè didžiuli skausmą, neleidžianti vaikščioti, - 10) po krūvio praejjus $24 \mathrm{~h}$.

Tyrimo eiga. Iš viso atlikti trys eksperimentai - kai raumuo buvo iprastinès temperatūros, pašildytas ir pašaldytas. Tarp tyrimų daryta ne mažesnè kaip mėnesio pertrauka. Eksperimentai vienas nuo kito skyrèsi tik tuo, kad antro metu tiriamujų, atliekančių izokinetinio krūvio testą, raumenu temperatūra buvo padidinta iki $39,5 \pm 0,3^{\circ} \mathrm{C}$, trečio - sumažinta iki $32,5 \pm 0,3^{\circ} \mathrm{C}$. Visuc eksperimentu eiga (kai raumuo buvo ITR, pašildytas ir pašaldytas) ta pati. Tiriamieji prieš kiekvieną eksperimentą buvo supažindinami su jo eiga ir mokomi atlikti pratimą. Kambario temperatūra viso tyrimo metu buvo pastovi $\left(20-22^{\circ} \mathrm{C}\right)$. Prieš šildymą ir šaldymą adatiniu termometru buvo matuojama (kontrolinè) vidinè raumenu temperatūra. Registruojant blauzdos tiesiamuju ir lenkiamuju raumenų rodiklius, buvo atlieka- mas kontrolinis matavimas prieš krūvị ( 3 kartus tiesiant ir lenkiant koją per kelio sąnarị fiksuotu $180^{\circ} / \mathrm{s}$ greičiu) ir praejjus $10,30,60 \mathrm{~min}$ ir $24 \mathrm{~h}$ po jo. Poilsis tarp matavimų, esant skirtingam kampiniam greičiui, - $60 \mathrm{~s}$. Koncentrinis krūvis - 50 blauzdos tiesimų ir lenkimų $180^{\circ} / \mathrm{s}$ greičiu. Vidinès raumenų temperatūros matavimo procedūra pakartotinai atlikta iš karto po raumenų šildymo, šaldymo ir po koncentrinio krūvio. Kreatinkinazès (CK) aktyvumas kraujo serume nustatomas prieš krūvị ir praejus $24 \mathrm{~h}$ po jo. Raumenų skausmas subjektyviai vertinamas balais po krūvio praèjus $24 \mathrm{~h}$.

Statistiniai skaičiavimai. Tyrimo duomenys išanalizuoti aprašomosios ir sudètingesnès statistinès analizès metodais, naudojant programinius Microsoft ${ }^{\circledR}$ Excel 2003 ir SPSS paketus. Skirtumo tarp aritmetinių vidurkiu reikšmingumas buvo nustatomas pagal dvipusį nepriklausomų imčių Stjudento $t$ kriterijų. Lyčių, skirtingos temperatūros vidurkių skirtumo statistiniam reikšmingumui ivertinti naudotas dviejų, trijų ir keturių veiksnių dispersinès analizès modelis. Skirtumas statistiškai reikšmingas, kai $\mathrm{p}<0,05$.

\section{REZULTATAI}

Vyrų ir moterų blauzdos tiesiamujų (1 pav.) ir lenkiamuju (2 pav.) raumenu MJM iš karto po krūvio (50-o susitraukimo metu) statistiškai patikimai sumažèjo, palyginti su kontroline reikšme (prieš krūvi) $(\mathrm{p}<0,05)$. Praejjus 10 ir 30 min po koncentrinio krūvio, nustatytas reikšmingas ITR ir pašildytu, pašildytų ir pašaldytų vyrų blauzdos tiesiamuju (1 pav.) raumenu jègos pokyčio skirtumas $(\mathrm{p}<0,05)$. Blauzdos lenkiamuju (2 pav.) raumenu
1 pav. Vyrų ir moterų maksimaliosios jègos momento $(\mathrm{N} \cdot \mathrm{m})$ rodiklių kaita tiesiant koją per kelio sąnarị fiksuotu $180^{\circ} / \mathrm{s}$ greičiu
Pastaba. * - p $<0,05-$ maksimaliosios jègos momento rodiklis reikšmingai pakito, palyginti su kontroline reikšme; $\#-\mathrm{p}<0,05$ - iprastinès temperatūros ir pašaldytu raumenu jègos pokyčio skirtumas; $\wedge$ - $p<0,05-$ pašaldytu ir pašildytų raumenu jègos pokyčio skirtumas; $£-p<0,05$ - iprastinès temperatūros ir pašildytų raumenu jẻgos pokyčio skirtumas.

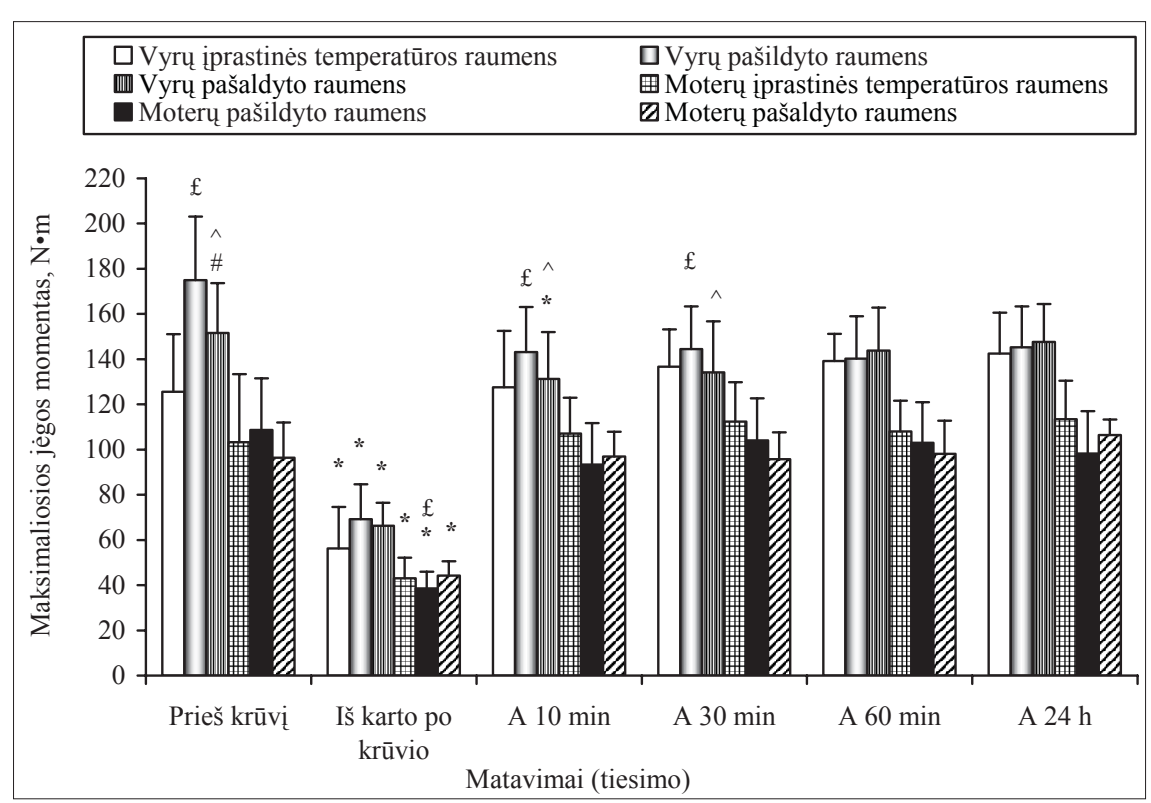



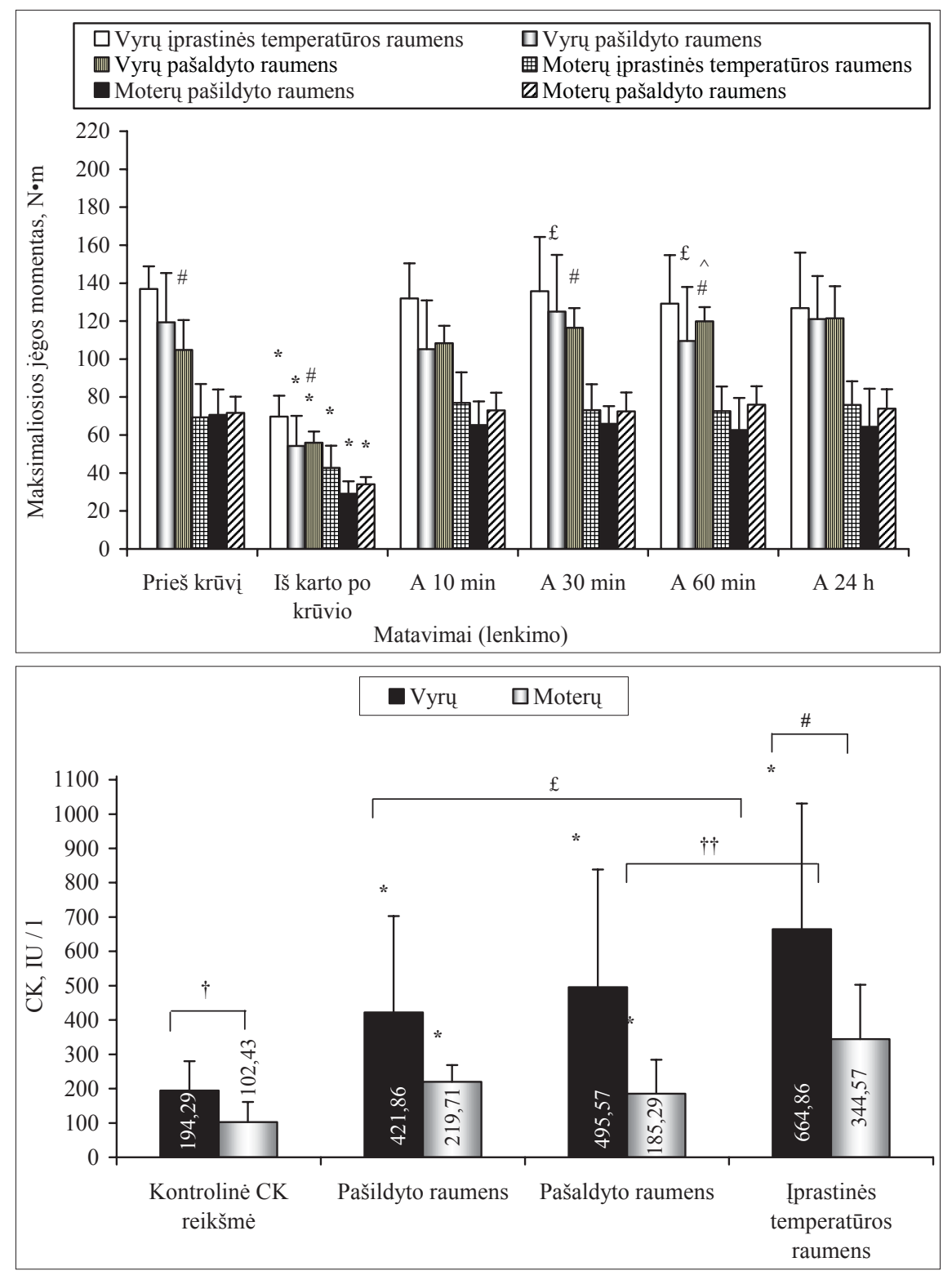

2 pav. Vyrų ir moterų maksimaliosios jègos momento $(\mathrm{N} \cdot \mathrm{m})$ rodikliu kaita lenkiant koją per kelio sąnarị fiksuotu $180^{\circ} / \mathrm{s}$ greičiu
Pastaba. * - p $<0,05-$ maksimaliosios jẻgos momento rodiklis reikšmingai pakito, palyginti su kontroline reikšme; $\#-\mathrm{p}<0,05-$ iprastinès temperatūros ir pašaldytu raumenu jègos pokyčio skirtumas; ${ }^{\wedge}-p<0,05-$ pašaldytu ir pašildytų raumenų jègos pokyčio skirtumas; $£-p<0,05$ - iprastinès temperatūros ir pašildytų raumenų jègos pokyčio skirtumas.

3 pav. Kreatinkinazès (CK) aktyvumas kraujo serume $1 \mathrm{~h}$ prieš krūvị ir praèjus 24 h po jo jègos reikšmingas skirtumas nustatytas praejjus 30 ir 60 min po krūvio, kai raumenys buvo ITR ir pašildyti, o vyru - ITR ir pašaldyti $(\mathrm{p}<0,05)$. Praèjus $24 \mathrm{~h}$ po krūvio, reikšmingo skirtumo nenustatyta $(\mathrm{p}>0,05)(1,2$ pav.).

Testavimo metu aptikta, kad moteru maksimaliosios jejgos momento nuovargio indeksas $(\mathrm{NI})$, tiesiant $(\mathrm{p}=0,004)$ ir lenkiant $(\mathrm{p}=0,016)$ koją per kelio sąnari fiksuotu $180^{\circ} / \mathrm{s}$ greičiu, priklauso nuo laiko. Nustatyta reikšminga sąveika tarp: laiko, temperatūros ir raumenų atliekamo darbo (tiesimo-lenkimo) $(\mathrm{p}=0,018)$; laiko, temperatūros ir lyties $(\mathrm{p}=0,000)$; temperatūros, raumenu atliekamo darbo (tiesimo-lenkimo) ir lyties $(\mathrm{p}=0,002)$ (žr. lent.). Vyrų maksimaliosios jejgos momento nuovargio indeksas, tiesiant koją per kelio sąnari fiksuotu $180^{\circ}$ / s greičiu, priklauso nuo laiko $(\mathrm{p}=0,041)$ ir temperatūros $(p=0,004)$. Nustatyta reikšminga laiko ir tem- peratūros sąveika $(p=0,017)$. Lenkiant koją per kelio sąnari fiksuotu $180^{\circ} / \mathrm{s}$ greičiu, NI priklauso nuo laiko $(\mathrm{p}=0,022)$. Tarp laiko ir temperatūros $(\mathrm{p}=0,002)$, tarp laiko, temperatūros ir raumenu atliekamo darbo (tiesimo-lenkimo) $(\mathrm{p}=0,000)$ nustatyta reikšminga sąveika (žr. lent.).

Tiek vyrų, tiek moterų kreatinkinazès (CK) aktyvumas kraujo serume, praejus $24 \mathrm{~h}$ po koncentrinio krūvio, reikšmingai padidejo, palyginti su kontroline reikšme $(\mathrm{p}<0,05)$, kai raumuo buvo iprastinès temperatūros, pašildytas ir pašaldytas. Nustatyta, kad moteru CK aktyvumas kraujo serume reikšmingai skiriasi, kai raumenys ITR ir pašaldyti, vyrų - ITR ir pašildyti $(p<0,05)$. Lyginant vyrų ir moteru CK aktyvumo kraujo serume iprastinès temperatūros raumens reikšmes, praejjus $24 \mathrm{~h}$ po krūvio, nustatytas statistiškai reikšmingas skirtumas $(\mathrm{p}<0,05)(3$ pav. $)$. 


\begin{tabular}{|c|c|c|c|c|c|}
\hline \multirow{14}{*}{$\begin{array}{l}\text { Lentelè. Maksima- } \\
\text { liosios jègos mo- } \\
\text { mento nuovargio } \\
\text { indekso dispersinè } \\
\text { analizė }\end{array}$} & \multirow{2}{*}{ Priklausomumas nuo: } & \begin{tabular}{|l} 
Kojos \\
tiesimo
\end{tabular} & \begin{tabular}{|l|} 
Kojos \\
lenkimo \\
\end{tabular} & \begin{tabular}{|l} 
Kojos \\
tiesimo
\end{tabular} & \begin{tabular}{|l} 
Kojos \\
lenkimo \\
\end{tabular} \\
\hline & & \multicolumn{2}{|l|}{ Vyrų } & \multicolumn{2}{|l|}{ Moterų } \\
\hline & Laiko: & $\mathrm{p}=0041$ & $\mathrm{p}=0,022$ & $\mathrm{p}=0,004$ & $\mathrm{p}=0,016$ \\
\hline & Temperatūros & $\mathrm{p}=0,004$ & $\mathrm{p}=0,339$ & $\mathrm{p}=0,445$ & $\mathrm{p}=0,023$ \\
\hline & Sąveika (laikas-temperatūra) & $\mathrm{p}=0,017$ & $\mathrm{p}=0,002$ & $\mathrm{p}=0,581$ & $\mathrm{p}=0,675$ \\
\hline & Raumenu atliekamo darbo (tiesimo-_lenkimo) & \multicolumn{2}{|l|}{$\mathrm{p}=0,696$} & \multicolumn{2}{|l|}{$\mathrm{p}=0,149$} \\
\hline & Sąveika (laikas_raumenų atliekamas darbas) & \multicolumn{2}{|l|}{$\mathrm{p}=0,086$} & \multicolumn{2}{|l|}{$\mathrm{p}=0,030$} \\
\hline & Sąveika (temperatūra- raumenų atliekamas darbas) & \multicolumn{2}{|l|}{$\mathrm{p}=0,003$} & \multicolumn{2}{|l|}{$\mathrm{p}=0,018$} \\
\hline & Sąveika (laikas-temperatūra-raumenų atliekamas darbas) & \multicolumn{2}{|l|}{$\mathrm{p}=0,000$} & \multicolumn{2}{|l|}{$\mathrm{p}=0,727$} \\
\hline & Lyties: & \multicolumn{4}{|l|}{$\mathrm{p}=0,021$} \\
\hline & Sąveika (laikas-lytis) & \multicolumn{4}{|l|}{$\mathrm{p}=0,380$} \\
\hline & Sąveika (temperatūra-lytis) & \multicolumn{4}{|l|}{$\mathrm{p}=0,013$} \\
\hline & Sąveika (raumenu atliekamas darbas-lytis) & \multicolumn{4}{|l|}{$\mathrm{p}=0,306$} \\
\hline & Sąveika (laikas—-temperatūra-lytis) & \multicolumn{4}{|l|}{$\mathrm{p}=0,000$} \\
\hline
\end{tabular}

Praejus 24 h po koncentrinio krūvio, nenustatytas reikšmingas raumenų skausmo (ir vyrų, ir moteru) skirtumas ( $p>0,05)$, kai raumuo buvo iprastinès temperatūros (vyrų - 1,9 b., moteru $-2,3$ b.), pašildytas (vyrų - 2,35 b., moteru - 2,5 b.) ir pašaldytas (vyrų $-2,9$ b., moteru -3 b.).

\section{REZULTATŲ APTARIMAS}

Pagrindiniai tyrimo duomenys parodè, kad tiek šildymas, tiek šaldymas prieš koncentrini krūvị sumažino netiesiogini raumenų pažeidos simptomą - kreatinkinazès kieki kraujyje praejjus $24 \mathrm{~h}$ po krūvio, tačiau raumenų skausmo temperatūra nepakeitè. Pasyvus šildymas ir šaldymas nepakeite nei vyrų, nei moterų raumenų nuovargio, atliekant koncentrinius pratimus (50 kojos tiesimu—lenkimų) vidutiniu $\left(180^{\circ} / \mathrm{s}\right)$ greičiu.

Koncentrinis krūvis mažina raumenų atsparumą ekscentrinių krūvių sukeliamai pažeidai (Gleeson et al., 2003). Manoma, kad ekscentriniu susitraukimu metu aktyvinamas mažesnis motoneuronų kiekis, negu atliekant to paties galingumo koncentrinius susitraukimus, todèl pažeida yra didesnè (Enoka, 1996). Mūsų tyrimo duomenys rodo, kad skirtinga raumenų temperatūra prieš koncentrinị krūvị sumažino netiesioginị raumenu pažeidos simptomą - kreatinkinazès aktyvumą kraujo serume praejjus $24 \mathrm{~h}$ po krūvio, tačiau raumenų skausmo temperatūra nepakeitė atliekant koncentrinius pratimus (50 kojos tiesimu—lenkimų) vidutiniu $\left(180^{\circ} / \mathrm{s}\right)$ greičiu. Z. Zainuddin ir kt. (2006) iškèlè hipotezę, kad atlikus koncentrini krūvị, palyginti su ekscentriniu, sumažès raumenu skausmas ir raumuo greičiau atsigaus po pažeidos, tačiau padarè išvadą, kad po koncentrinio krūvio raumenų skausmas buvo mažesnis, palyginti su ekscentriniu, o raumuo greičiau neatsigavo (Zai- nuddin et. al., 2006). Pažeidus raumeni, gali suirti jo sarkomeru struktūra, miofibrilès, citoskeleto baltymai, sarkolema, sumažèti ir ilgai neatsigauti valingoji ir nevalingoji raumenų susitraukimo jèga, taip pat kreatinkinazè gali ištekèti iš pažeistų raumeninių skaidulų, gali vykti uždegiminès reakcijos - raumenys gali sustandèti, pabrinkti ir ilgai skaudèti (Friden, Lieber, 1992; Clarkson, Hubal, 2002; Byrne et al., 2004). Vidinè ląstelių pažeida sukelia uždegimo procesus ir skausmą, kuris atsiranda praejjus 24-72 valandoms po fizinio krūvio ir atslūgsta po 5-7 dienų (Cleak and Eston, 1992). Per mechaniškai valdomus $\mathrm{Ca}^{2+}$ kanalus arba įtrūkus sarkoplazminiam tinklui, $\mathrm{T}$ vamzdeliams ar sarkolemai i sarkoplazmą patenka didesnès koncentracijos $\mathrm{Ca}^{2+}$ ir sukelia filamentų, palaikančių selektyvią sarkomero struktūrą, hidrolizę arba irimą (Friden, Lieber, 1992). Sumažinus raumenų temperatūrą, sulèteja nervo laidumo greitis ir raumens verpstès aktyvumas. Atlikto tyrimo duomenys sutampa su R. Eston ir D. Peters (1999), S. Sipavičienès ir kt. (2004) gautaisiais — pažeistu raumenų šaldymas, naudojant šalto vandens vonią, sumažino kreatinkinazès aktyvumą kraujo serume po krūvio praejus $24 \mathrm{~h}$. Tai paaiškinama: kai po lokalaus raumenų šaldymo sumažeja limfos ir kraujo kapiliaru pralaidumas, mažiau kreatinkinazès patenka į raumens limfinę sistemą (Eston and Peters, 1999).

Atlikto tyrimo rezultatai rodo, kad pasyvus šildymas ir šaldymas nepakeitė nei vyru, nei moteru raumenų nuovargio, atliekant koncentrinius pratimus (50 kojos tiesimų-lenkimų) vidutiniu $\left(180^{\circ} / \mathrm{s}\right)$ greičiu. Po ekscentrinių ir koncentriniu pratimų raumenų skausmą lydi ne tik raumenų sustingimas, skausmas judesio metu, jautrumas ir patinimas, bet ir jẻgos mažejimas (Sayers et al., 2000; Clarkson, Hubal, 2002; Ramanauskienè ir 
kt., 2006 a). Raumenų nuovargio pobūdis priklauso nuo raumenų darbo arba aktyvumo tipo. Aukšta aplinkos temperatūra (Galloway and Moughan, 1997) ir padidèjusi vidinè organizmo temperatūra (Gonzalez-Alonso et al., 1999) pagreitina nuovargio atsiradima, atliekant didelio intensyvumo pratimus. B. Nielsen ir kt. (2001) nustate, kad atlikus fizini krūvi aukštos aplinkos temperatūros sąlygomis, vidinè raumenų temperatūra pakyla iki $39^{\circ} \mathrm{C}$. Tai gali būti tiesioginè priežastis, dèl ko atsiranda nuovargis centrinejje nervų sistemoje. Vidinès temperatūros pakèlimas daugiau kaip $3^{\circ} \mathrm{C}$ yra savotiškas slenkstis, kuri peržengus dèl sutrikusios termoreguliacijos ribojamos žmogaus fizinès galios (Kaciuba-Uscilko et al., 1992). At- likto tyrimo duomenys sutampa su minètų autorių gautaisiais: vidinè raumenų temperatūra po $45 \mathrm{~min}$ šildymo pakilo iki $39,5^{\circ} \mathrm{C}$ (pradinè $-36,9^{\circ} \mathrm{C}$ ), atlikus koncentrini krūvi - iki $41,1^{\circ} \mathrm{C}$.

\section{IŠVADOS}

Tiek šildymas, tiek šaldymas prieš koncentrini krūvị sumažino netiesioginị raumenų pažeidos simptomą - kreatinkinazès kiekị kraujyje praejjus $24 \mathrm{~h}$ po krūvio, tačiau raumenų skausmo temperatūra nepakeitè. Pasyvus šildymas ir šaldymas nepakeitè nei vyrų, nei moterų raumenų nuovargio, atliekant koncentrinius pratimus vidutiniu greičiu.

\section{LITERATŪRA}

Booth, J., Marino, F. and Ward, J. J. (1997). Improved running performance in hot humid condition following whole body precooling. Medicine and Science in Sports and Exercise, 29, 943-949.

Byrne, R. M., Twist, C., Eston, R. (2004). Neuromuscular function after exercise-induced muscle damage. Theoretical and Applied Implications. Sports Medicine, 34 (1), 49-69.

Clarkson, P. M., Hubal, M. J. (2002). Exercise-induced muscle damage in humans. American Journal of Physiology and Medicine Rehabilitation, 81 (11), S 52-69.

Clarkson, P. M., Newham, D. J. (1995). Associations between muscle soreness, damage, and fatigue. Advances in Experimental Medicine and Biology, 384, 457-469.

Clarkson, P. M., Sayers, S. P. (1998). Exercise-induced muscle damage in human. In H. Nose, E. R. Nadel and K. Morimoto (Eds.), Nagano Symphosium on Sports Science (pp. 545-563). Carmel, IN: Cooper Publishing Group.

Cleak, M. J. and Eston, R. G. (1992). Muscle soreness, swelling, stiffness and strenght loss after intense eccentric exercise. Britich Journal of Sports Medicine, 26, 267-272.

Enoka, R. M. (1996). Eccentric contractions require unique activation strategies by the nervous system. Journal of Applied Physiology, 81, 2339-2346.

Eston, R., Peters, D. (1999). Effect of cold water immersion on the symptoms of exercise-induced muscle damage. Journal of Sports Science, 17 (3), 231-238.

Febbraio, M. A. (2000). Does muscle function and metabolism affect exercise perfomance in the heat? Exercise and Sport Science Reviews, 28, 171-176.

Friden, J., Lieber, R. L. (1992). Structural and mechanical basis of exercise-induced muscle injury. Medicine Science of Sports Exercise, 24, 521-530.

Galloway, S. D. R. and Moughan, R. J. (1997). Effects of ambient temperature on the capacity to perform prolonged exercise in humans. Medicine and Science in Sports and Exercise, 29, 1240-1249.

Gleeson, N., Eston, R., Marginson, V., McHugh, M. (2003). Effects of prior concentric training on eccentric exercise indused muscle damage. British Journal of Sports Medicine, 37, 119-125.

Gonzalez-Alonso, J., Teller, C., Anderson, S. L. et al. (1999). Influence of body temperature on the development of fatigue during prolonged exercise in the heat. Journal of Applied Physiology, 86, 1032-1039.

Janse de Jonge, X. A. K. (2003). Effects of the menstrual cycle on exercise performance. Sports Medicine, 33 (11), 833 - 851 .

Kaciuba-Uscilko, H., Kruk, B., Szejczewska, M. et al. (1992). Methabolic, body temperature and hormonal responses to reated periods of prolonged cycle ergometer exercise in men. European Journal of Applied Physiology, 64, 26-31.

Meeusen, R. and Lievens, I. (1986). The use of cry therapy in sport injuries. Sports Medicine, 3, 398-414.

Nielsen, B., Hylding, T., Bidstrup, F., Gonzalez-Alonso, J., Christoffersen, G. R. (2001). Brain activity anf hatique during prolonged exercise in the heat. Pflugers Archive, $442,41-48$

Nosaka, K., Newton, M., Sacco, P. (2002). Muscle damage and soreness after endurance exercise of the elbow flexors. Medicine Science and Sports Exercise, 34 (6), 920-927. Prentice, W. E. (1982). An electromyographic analyse of the effectiveness of heat or cold and stretching for inducing relaxation in injured muscle. Journal Orthopedic and Sports Physiology Therapy, 3, 133-140.

Ramanauskienė, I., Brazaitis, M., Skurvydas, A. ir kt. (2006 a). Skirtingos temperatūros poveikis kelio tiesiamujų ir lenkiamujų raumenų nuovargiui ir atsigavimui. Ugdymas. Küno kultūra. Sportas, 2 (61), 45-52.

Ramanauskienè, I., Skurvydas, A., Brazaitis, M. ir kt. (2006 b). Moteru ir vyru kelio tiesiamujuc ir lenkiamųjų raumenų susitraukimo funkcijos priklausomybè nuo temperatūros. Ugdymas. Kūno kultūra. Sportas, 3 (62), $49-55$.

Ratkevicius, A., Skurvydas, A., Povilonis, E., Quistroff, B. (1998). Effects of contraction duration on low- frequency fatigue in voluntary and electrically induced exercise of quadriceps muscle in humans. European Journal of Applied Physiology, 77 (5), 462-468.

Sargeant, A. J. (1987). Effect of muscle on leg extension force and short-term power output in humans. European Journal of Applied Physiology, 56, 693-698.

Sayers, S. P., Clarkson, P. M., Lee, J. (2000). Activity and immobilization after eccentric exercise: Recovery of 
muscle function. Medicine Science and Sports Exercise, 32 (9), 1587-1592.

Sayers, S. P., Clarkson, P. M. (2003). Short-term immobilization after eccentric exercise. Part II: Creatine kinase and myoglobin. Medicine Science and Sports Exercise, 5, $762-768$.

Sipavičienè, S., Skurvydas, A., Mickevičienè, D. ir kt. (2004). Raumens šaldymo poveikis žmogaus griaučiu raumenų susitraukimo savybèms. Ugdymas. Küno kultūra. Sportas, 1 (51), 47-51.

Skurvydas, A., Jascianinas, J., Zachovajevas, P. (2000).
Changes in height of jump, maximal voluntary contraction force and low-frequency fatigue after 100 intermittent or continuous jumps with maximal intensity. Acta Physiologica Scandinavica, 169, 55-62.

Warren, G. L., Lowe, D. A., Armstrong, R. B. (1999). Measurement tools used in the study of eccentric contractioninduced injury. Sports Medicine, 27 (1), 43-59.

Zainuddin, Z., Sacco, P., Newton, M., Nosaka, K. (2006). Light concentric exercise has a temporarily analgesic effect on delayed - onset muscle soreness, but no effect on recovery from eccentric exercise. Applied Physiology, Nutrition and Metabolism, 31 (2), 126-134.

\title{
EFFECT OF CONCENTRIC CONTRACTION ON MUSCLE FATIGUE AND MUSCLE DAMAGE DEPENDING ON MUSCLE TEMPERATURE AND GENDER
}

\author{
Irina Ramanauskienè $\dot{e}^{1,2}$, Albertas Skurvydas ${ }^{1}$, Saulè Sipavičiene் $^{1}$, Dalia Mickevičiené ${ }^{1}$, \\ Laura Daniusevičiūtè $\dot{e}^{1,2}$, Vitas Linonis ${ }^{2}$ \\ Lithuanian Academy of Physical Education ${ }^{1}$, \\ Kaunas University of Technology', Kaunas, Lithuania
}

\begin{abstract}
The aim of the present study was to establish the influence of concentric contraction on muscle fatigue and muscle damage depending on temperature and gender. The participants of the study were 10 healthy males, aged 19-23 years; height $-177.8 \pm 5.8$; weight $-78.2 \pm 6.1$; body fat $-7,5 \%$ (body fat mass $5.6 \mathrm{~kg}$ ) and 10 females, aged $18-23$ years; height $-166.4 \pm 5.6$; weight $-56.2 \pm 6.1$; bodyfat $-17 \%$ (body fat mass - $10.7 \mathrm{~kg}$ ). The participants of the study were tested on isokinetic dynamometer (Biodex Medical System PRO 3). The type of concentric contraction was automatically established by the system exercising in isokinetic regimen. Control measuring ( 3 times of leg extension and leg flexion in the knee joint at the fixed speed of $180^{\circ} / \mathrm{s}$ ) was performed before the load, after $10 \mathrm{~min}, 30 \mathrm{~min}, 60 \mathrm{~min}$ and $24 \mathrm{~h}$ after the load; concentric load - 50 leg extensions and flexions in the knee joint at the fixed speed of $180^{\circ} / \mathrm{s}$. Before and after muscle cooling or heating and after physical load we measured muscle temperature with needle thermometer (Ellab A / S, tipe DM 852, Denmark). Creatine kinase activity in blood serum was estimated 1 hour prior to load and 24 hours after it. Muscle pain was estimated subjectively using a 10-point scale after 24 hours after the load. The evaluated parameter was the peak torque (measured in $\mathrm{N} \cdot \mathrm{m}$ ).

There was a significant increase $(\mathrm{p}<0.05)$ in creatine kinase $(\mathrm{CK})$ activity in the blood serum of both men and women after 24 hours after concentric load, compared to the control value, when the muscle was at its usual temperature, as well as after warming and cooling. A comparison of CK activity in the blood serum of men's and women's muscles at control temperature (1 hour prior to the load) and at their usual temperature after 24 hours after the load revealed a statistically significant difference $(\mathrm{p}<0.05)$. A comparison of CK activity in the blood serum of men was significant $(p<0.05)$ between muscles at their usual temperature and warmed muscles, and women - between muscles at their usual temperature and cooled muscles.

The evidence obtained in this study showed that both muscle warming and muscle cooling brought about a decrease in an indirect symptom of muscle damage - the amount of creatine kinase after 24 hours after concentric load, but temperature did not have any effect on the subjective muscle pain. Passive muscle warming and cooling did not cause any changes either in the rate of muscle fatigue performing concentric exercise (50 leg extensions-flexions) at average (speed of $180^{\circ} / \mathrm{s}$ ).
\end{abstract}

Keywords: knee extensors / flexors, passive muscle heating and cooling, gender.

Gauta 2007 m. vasario $12 \mathrm{~d}$.

Received on February 12, 2007

Priimta $2007 \mathrm{~m}$. balandžio $24 \mathrm{~d}$.

Accepted on April 24, 2007
Irina Ramanauskiené

Kauno technologijos universitetas

(Kaunas University of Technology)

Donelaičio g. 73, LT-44248 Kaunas

Lietuva (Lithuania)

E-mail Irina.Ramanauskiene@ktu.lt 